\title{
Aplikasi Model Pembelajaran Sinektik (Synectic Model)
}

\author{
Uus Karwati \\ Universitas Pendidikan Indonesia (UPI) Bandung \\ Jalan Dr. Setiabudi No. 229 Bandung
}

\begin{abstract}
The title of this article is Application of Synectic Learning Model in Kampung Seni \& Wisata Manglayang, Bandung regency. This paper is motivated by the idea of conceptualization necessities of learning in art studios which provide learning services to the visitors, especially of the early ages. The research used a qualitative paradigm with pseudo experiment approach of one short case study applying Synectic Learning Model that is an approach to develop creativity, to enhance problemsolving skills, creative expression, and to develop empathy in social relationships. Through its application the art learning activities in the studio visitation program is more meaningful and able to develop ideas and enhance creative activities of the students.
\end{abstract}

Keywords: Synectic Learning Model.

\section{Pendahuluan}

Pendidikan merupakan salah satu faktor penting bagi kemajuan hidup manusia yang berbudaya. Melalui kegiatannya pendidikan dapat dijadikan sebagai salah satu upaya pewarisan nilai-nilai luhur budaya bangsa kepada generasi penerusnya agar mereka tidak tercerabut dari akar-akar budayanya. Menurut Tilaar (1999) nilai-nilai budaya itu harus hidup, menghidupi, dan mengarahkan kehidupan masyarakatnya kini dan masa depan guna memperkuat jatidiri demi ketahanan bangsa. Oleh karena itu maka pembangunan pendidikan di
Indonesia diupayakan agar berbasis pada nilai-nilai budaya yang hidup di lingkungan masyarakatnyaagar membentuk individu yang mampu menjadi bagian dari komunitasnya.

Pembelajaran nilai-nilai seni budaya berdasarkan prosesnya diharapkan akan mampu mengembangkan kepribadian yang kreatif, sebagai landasan hidup agar kelak mampu mengembangkan dirinya sesuai nilai-nilai dan norma yang berkembang di berbagai lingkungannya. Untuk itu agar pembelajaran seni budaya dapat 
dipahami peserta didik dan agar mampu menumbuhkan perilaku kreatif, perlu diciptakan proses pembelajarannya yang mampu membangun kultur lokal sesuai dengan kondisi modern saat ini. Kemampuan ini kelak akan dapat memberikan sumbangan bagi generasi bangsa demi terwujudnya nilai-nilai global secara positif.

Proses pengenalan nilai-nilai budaya, melalui pendidikan formal di sekolahsekolah telah diupayakan baik dalam bentuk materi kurikulum inti maupun dalam kegiatan ekstrakurikuler. Namun demikian hal itu masih dirasakan belum memadai mengingat keterbatasan waktu, terkendala oleh sarana dan prasarana yang kurang mendukung, atau strategi yang kurang tepat sehingga penyampaiannya menjadi kurang maksimal. Untuk mengatasi persoalan itu, maka pihak sekolah ada yang mencoba melakukan upaya lain yakni dengan mengajak peserta didik mengenal seni budaya di luar lingkungan sekolah dengan mengunjungi sanggarsanggar seni yang menyediakan layanan kunjungan pembelajaran seni bagi peserta didik. Pembelajaran seni budaya di luar lingkungan sekolah formal di sanggarsanggar seni inilah berdasarkan prosesnya disebut sebagai pembelajaran secara non formal dalam bentuk pariwisata pendidikan seni.

Seperti halnya dalam lingkup pendidikan formal, maka proses layanan pembelajaran seni dalam kegiatan pariwisata pendidikan seni perlu dilakukan secara profesional agar peserta didik yang belajar seni budaya merasa senang, dapat merasakan kebermaknaannya karena mendapatkan pengalaman belajar seni budaya secara maksimal. Agar mencapai tujuan itu maka layanan proses pembelajaran seni budaya di sanggar seni perlu mengimple- mentasikan model pembelajaran yang inovatif dan dirancang sesuai dengan kondisi pembelajaran dan karakteristik peserta didik agar tujuan pembelajaran dapat tersampaikan secara maksimal.

Di wilayah kota Bandung, saat ini banyak berdiri sanggar-sanggar seni yang telah mengembangkan kegiatannya menjadi sanggar kunjungan pariwisata seni disamping sebagai pusat pelatihan seni. Namun secara umum sanggar-sanggar seni tersebut dalam menata layanan pembelajaran seni budayanya baru pada tahap apresiasi dalam bentuk penikmatan karya seni yang dilakukan secara pasif (menonton karya seni) tanpa mendapatkan pengalaman secara langsung. Akibatnya pemahaman kreatif dan kebermaknaannya belum dapat ditumbuhkan pada diri peserta didik.

Kendati demikian beberapa sanggar seni telah mencoba memberikan layanan pembelajaran seni secara langsung kepada peserta didikserta bentuk pelatihan seni. Salah satu sanggar yang telah berupaya melaksanakan proses kreatif dalam pembelajarannya adalah sanggar 'Kampung Seni \& Wisata Manglayang' yang berada di wilayah Ujungberung yang dikenal dengan nama Kampung Seni. Sanggar tersebut berdiri sejak tahun 2004 dibawah binaan Kawi dan Ria Fajaria sekaligus sebagai pimpinan sanggar. Proses pembelajaran seni bagi peserta didik di sanggar tersebut dapat berjalan dengan lancar, mengingat Kawi dan Ria berlatar belakang kesenimanan yang kuat di samping itu sebagai pendidik seni di salah satu institusi seni, yaitu di STSI Bandung. Sanggar Kampung Seni, seperti beberapa sanggar seni yang berbasis pariwisata pendidikan seni lainnya, juga tengah mengembangkan kegiatan layanan kunjungan dalam 
bentuk pembelajaran seni. Peserta didik yang melakukan kunjungan di sanggar itu diberi layanan pengalaman dan pemahaman seni melalui belajar seni secara langsung.

Namun demikian dalam pelaksanaannya, pihak pengelola sanggar masih mendapat kendala dalam pengelolaan pembelajaran antara lain: lingkup materi pembelajaran masih berbasis pada objek seni budaya setempat sehingga pengembangan materi pembelajaran masih dirasakan keterbatasannya. Perlunya strategi pembelajaran yang tepat khususnya bagi peserta didik dalam jenjang usia dini/usia tahap awal. Kendala lain yang dihadapi adalah pada saat memberi layanan pembelajaran dengan jumlah peserta didik yang melebihi kapasitas (lebih dari 30 orang) diperlukan strategi dan media yang memadai. Penyiapan media dalam jumlah banyak menjadi salah satu hambatan tidak terlaksananya proses pengembangan pembelajaran yang kreatif di sanggar tersebut.

Oleh karena itu dipandang perlu untuk menerapkan strategi pembelajaran yang sesuai dengan kriteria peserta didik serta dengan penerapan model pembelajaran yang tepat agar hasil pembelajaran lebih bermakna. Oleh karena itu perlu disusun strategi baru guna meningkatkan pemahaman dan memperbaiki proses pembelajaran untuk memudahkan siswa dalam belajar. Sesuai paparan Hamzah B. Uno (2007:v), bahwa pelaksanaan pembelajaran kegiatannya harus berupaya membelajarkan siswa secara terintegrasi dengan memperhitungkan faktor lingkungan belajar, karakteristik siswa, strategi pembelajaran, penyampaian, dan pengelolaan maupun pengorganisasian pembelajaran.

Berdasarkan latar belakang tersebut maka dicoba diaplikasikan model pembe- lajaran sinektik dalam layanan kunjungan pariwisata seni bagi peserta didik usia tahap awal di Sanggar Kampung Seni \& Wisata Manglayang guna mengatasi berbagai kendala yang dihadapi dalam proses pembelajarannya.

\section{Metode Penelitian}

Guna mendapatkan data sesuai harapan, maka proses pembelajaran sinektik diterapkan dalam bentuk eksperimen. Mengingat sifat kunjungan peserta didik di Sanggar Kampung Seni berlaku secara singkat dan tidak berulang-ulang, maka eksperimen yang dirancang yakni dalam bentuk eksperimen semu dalam bentuk one short case study (Sugiyono: 2007, Creswell, John W. (2003). Sample penelitian yakni peserta didik usia tingkat awal yang berkunjung di Sanggar Kampung Seni, berjumlah 75 orang. Sesuaidengan kondisi peserta didik, maka materi yang diimplementasikan bertema mengenal lingkungan khususnya keindahan binatang unggas 'ayam'. Strategi pembelajaran menerapkan pendekatan secara partisipatif (Sudjana: 2005:2) yakni pendidik menguasai metode dan teknik pembelajaran, memahami materi atau bahan belajar yang cocok dengan kebutuhan belajar dan berperilaku membelajarkan peserta didik. Penelitian ini diharapkan memberi kontribusi positif terhadap pengembangan pendidikan non formal, tercipta model pembelajaran seni untuk tujuan pariwisata pendidikan baik secara praktis maupun teoritis, dan dirasakan manfaatnya bagi pihak yang terkait.

Penelitian ini menerapkan model pembelajaran sinektik. Model mengajar atau model pengajaran menurut Dahlan 
(1984:21), dapat diartikan sebagai suatu rencana atau pola yang digunakan dalam menyusun kurikulum, mengatur materi pengajaran dan memberi petunjuk kepada pengajar dalam setting pengajaran ataupun setting lainnya yang ditentukan sesuai dengan tujuan pengajarannya. Dijelaskan Joyce dan Weil (1986:2) bahwa jantung dari proses mengajar adalah mengatur lingkungan sedemikian rupa sehingga siswa dapat melakukan interaksi. Selanjutnya Joyce dan Weil (1986:2) menyatakan bahwa: suatu model mengajar merupakan kerangka atau pola yang dapat digunakan untuk merancang pengajaran langsung di kelas maupun secara tutorial, dan dapat digunakan pula untuk mengemas materi pengajaran ... (Joyce dan Weil, 1986:2). Dengan demikian maka model mengajar harus mengikuti kebutuhan peserta didik.

Adapun model pembelajaran sinektik, berlandaskan konsep J.J. Gordon dan kawan-kawan yakni merupakan suatu pendekatan pembelajaran guna mengembangkan kreativitas. Menurut Gordon (Dahlan: 1984:87, Bruce Joyce, dkk.: 2009), model ini dimaksudkan untuk meningkatkan kemampuan memecahkan masalah, ekspresi kreatif, empati, dalam hubungan sosial. Penekanan pada ide-ide yang bermakna dapat meningkatkan aktivitas kreatif melalui bantuan daya pikir yang lebih kaya. Proses kreatif dapat dimanfaatkan untuk melatih individu guna meningkatkan kreatifitas peserta didik. Untuk menggambarkan model mengajar sinektik maka harus dianalisis berdasarkan konsep berikut: 1) Pentahapan langkah-langkah (syntax), 2) Sistem sosial dalam model, 3) Prinsip mereaksi antara murid dan guru, 4) Sistem penunjang yang diharapkan.

Syntax atau pentahapan langkah-langkah adalah gambaran model yang diurai- kan ke dalam serangkaian kegiatan yang konkrit di dalam kelas, untuk melihat kegiatan apa saja yang dilakukan di kelas, bagaimana memulainya, serta apa yang harus dikerjakan setelah langkah tersebut. Syntax tergantung tujuan instruksional atau hasil yang ingin dicapai dari pembelajaran.

Sistem sosial merupakan gambaran tentang peran guru dan siswa, hubungan diantara keduanya dan norma yang dibangun dalam model tersebut. Ada kalanya guru bertindak sebagai orang paling aktif dalam pengendalian pembelajaran, ada pula yang sebaliknya atau membagi peran guru dan siswa secara berimbang. Guru/pendidik bertindak sebagai reflektor atau memberikan kemudahan kepada kegiatan murid.

Prinsip mereaksi antara murid dan guru adalah bagaimana seharusnya guru memandang dan memberikan respons pada siswa, menghargai murid (to regard) dan merespons murid. Misalnya memberikan penghargaan pada peserta didik terbaik yang sanggup mengerjakan tugas, untuk menstimulus siswa lain, atau menumbuhkan kepercayaan diri pada setiap siswa bahwa masing-masing punya kelebihan.

Sistem penunjang atau sistem pendukung yang diharapkan adalah segala sarana bantuan dan alat yang diperlukan untuk melaksanakan model tersebut. Misalnya, kebutuhan ruangan yang luas, kelengkapan peralatan sebagai pendukung, atau sesuatu yang berada dibalik keterampilan manusia dan kapasitas serta teknik-teknik pemudahan untuk siswa. Syntax model sinektik dirancang seperti dapat dilihat pada tabel 1.

Evaluasi hasil pembelajaran yakni melihat hasil komparasi antara pre-test 


\begin{tabular}{|c|c|}
\hline $\begin{array}{l}\text { Tahap pertama: mendeskripsikan kondisi yang dia- } \\
\text { mati siswa (input substantif). }\end{array}$ & ranap Keaud. anaiog \\
\hline $\begin{array}{l}\text { Guru menyuruh siswa untuk mendeskripsikan situ- } \\
\text { asi atau topik yang mereka lihat saat ini (informasi } \\
\text { tentang topik baru). }\end{array}$ & $\begin{array}{l}\text { Para siswa mengusulkan analogi-analogi langsung, } \\
\text { memilihnya, dan mengeksplorasi (mendeskripsi- } \\
\text { kan)-nya lebih jauh. }\end{array}$ \\
\hline Tahap ketiga: analog personal. & Tahap keempat: konflik padat. \\
\hline Tahap kelima: analogi langsung. & $\begin{array}{l}\text { Tahap keenam: melihat apa yang dikerjakan sesuai } \\
\text { tugas awal. }\end{array}$ \\
\hline $\begin{array}{l}\text { Para siswa membuat dan memilih analogi langsung } \\
\text { yang lain, yang didasarkan pada analogi konflik pa- } \\
\text { dat. }\end{array}$ & $\begin{array}{l}\text { Guru meminta siswa kembali pada tugas masalah } \\
\text { awal dan menggunakan analogi tentang seluruh pen- } \\
\text { galaman sinektiknya. }\end{array}$ \\
\hline
\end{tabular}

Tabel 1

Syntax Pembelajaran

(Gordon dalam Bruce Joyce: 2009:258 dan Dahlan: 1984:94) dan post-test dengan menggunakan uji ' $t$ '. Data tersebut diperlukan guna mengetahui ada tidaknya peningkatan hasil yang signifikan antara pre-test dengan post-test yang mencakup ranah kognitif, afektif, dan psikomotor melalui penerapan model pembelajarannya (Sugiyono, 2008).

\section{Hasil Penelitian dan Pembahasan}

Studi eksperimen ini dilaksanakan di Sanggar 'Kampung Seni \& Wisata Manglayang', pimpinan Kawi dan Ria. Model sinektik diimplementasikan terhadap peserta didik usia dini yang berjumlah 75 orang yang berkunjung di sanggar tersebut. Model pemebelajaran dirancang sebagai upaya untuk mengatasi kesulitan pengelola sanggar dalam melaksanakan pembelajaran yang kreatif dan inovatif dengan kapasitas jumlah peserta didik yang banyak. Selain itu membantu mengatasi kesulitan penyediaan materi dan media pembelajaran untuk peserta didik dengan jumlah yang banyak.

Tema pengenalan lingkungan dengan objek mengenal keindahan binatang unggas 'ayam', dijadikan stimulus dalam proses pembelajaran seni yang meliputi pembelajaran musik imitatif dengan media suara mulut, dan pembelajaran gerak yang mengimitasi keindahan gerak-gerik binatang 'ayam'. Proses pembelajaran ini dipimpin instruktur Ria serta dibantu oleh instruktur binaan yakni Eggy, Hesty, dan Rina. Proses pembelajaran berlangsung selama 45 menit, yang dilaksanakan oleh semua peserta didik secara aktif. Syntax pembelajaran sinektik diimplementasikan seperti dapat dilihat pada tabel 2.

Pelaksanaan model pengajaran sinektik bagi peserta didik usia tingkat awal di Sanggar Kampung Seni, dapat dikatakan cukup berhasil dan mampu mengatasi berbagai kesulitan yang dihadapi pengelola sanggar. Menerapkan berbagai metode yakni: ceramah, tanya jawab, diskusi, eksplorasi, dan penugasan. Hasil yang didapat antara lain: 1) dapat mengatasi kesulitan penyediaan media belajar untuk menghadapi jumlah peserta didik yang banyak namun proses pembelajaran tetap aktif dan kreatif, 2) dapat mengatasi kesulitan instruktur dalam menentukan model pembelajaran yang tepat dan inova- 


\begin{tabular}{|c|c|c|}
\hline Tahap & Konsep Sinektik & Aplikasi \\
\hline 1 & $\begin{array}{l}\text { Input substantif: Instruktur meminta peserta didik } \\
\text { mendeskripsikan perilaku yang mereka lihat }\end{array}$ & $\begin{array}{l}\text { Peserta didik mendeskripsikan dan mengek- } \\
\text { splorasi gerak perilaku binatang 'ayam', dan } \\
\text { mendeskripsikan ciri-ciri suara ayam. Serta } \\
\text { mengamati bentuk dan rupa binatang ayam. }\end{array}$ \\
\hline 2 & $\begin{array}{l}\text { Peserta didik mengusulkan analogi-analogi } \\
\text { langsung, memilihnya, dan mengeksplorasi/ } \\
\text { mendeskripsikan-nya lebih jauh }\end{array}$ & $\begin{array}{l}\text { Peserta didik melakukan tahap eksplorasi gerak } \\
\text { yang bersifat imitatif sesuai yang mereka pilih } \\
\text { yang bersumber dari gerak ayam, serta eksplora- } \\
\text { si bunyi imitatif dari kesan bunyi ayam. } \\
\text { Pada kegiatan seni rupa peserta didik menye- } \\
\text { but alat dan bahan menggambar serta menye- } \\
\text { butkan perilaku jenis binatang ayam yang me- } \\
\text { reka kenal. }\end{array}$ \\
\hline 3 & $\begin{array}{l}\text { Analog langsung: } \\
\text { Instruktur meminta peserta didik untuk meng- } \\
\text { utarakan temuannya (analogi-analogi langsung), } \\
\text { memilihnya, dan mengeksplorasi (mendeskripsi- } \\
\text { kannya) terkait yang diamati. }\end{array}$ & $\begin{array}{l}\text { Peserta didik mempraktikkan hasil eksplorasi } \\
\text { gerak dan bunyi dalam bentuk gerak dan musik } \\
\text { mulut imitatif dari sumber yang diamati yakni } \\
\text { binatang ayam. } \\
\text { Gerak dan musik diterapkan dengan konsep hi- } \\
\text { tungan sederhana: } t u, w a, g a \text {, pat, sebagai bagian } \\
\text { dari pemahaman ritmik, dengan tempo sedang. }\end{array}$ \\
\hline 4 & $\begin{array}{l}\text { Analog personal: } \\
\text { peserta didik (menjadi analogi) memetakan/ } \\
\text { menerapkan hasil eksplorasi tentang apa yang } \\
\text { telah mereka pilih pada tahap } 2 \text {. }\end{array}$ & $\begin{array}{l}\text { Setelah setiap motif gerak dan motif musik } \\
\text { dipahami peserta didik, kemudian atas instruk- } \\
\text { si instruktur peserta didik berlatih tiap bentuk } \\
\text { gerak sesuai dengan irama yang disarankan } \\
\text { serta merangkaikannya. }\end{array}$ \\
\hline 5 & $\begin{array}{l}\text { Konflik padat: peserta didik mempraktikkan ha- } \\
\text { sil pilihan idenya dari tahap } 2 \text { dan } 3 \text { (berlatih) } \\
\text { didorong untuk membuat analogi lebih kreatif. }\end{array}$ & $\begin{array}{l}\text { Pada tahap ini peserta didikmencoba merang- } \\
\text { kaikan motif gerak dengan hitungan yang kon- } \\
\text { stan, dan mengarahkan penerapan ekspresi. } \\
\text { Instruktur membimbing kesesuaian antara ge- } \\
\text { rak dan musik. }\end{array}$ \\
\hline 6 & $\begin{array}{l}\text { Analogi terakhir:peserta didik mempraktikkan } \\
\text { analogi terakhir dan seluruh pengalaman sinek- } \\
\text { tiknya: mendeskripsikan, membuat perbandin- } \\
\text { gan dari sumber pertama yang menjadi stimulus- } \\
\text { nya. }\end{array}$ & $\begin{array}{l}\text { Pada tahapan ini peserta didik melakukan unjuk } \\
\text { kerja dengan mempraktikkan kemampuannya } \\
\text { didepan teman-temannya secara berkelompok. } \\
\text { Kemudian diberi komentar dengan bimbingan } \\
\text { instruktur. }\end{array}$ \\
\hline
\end{tabular}

Tabel 2

Hasil implementasi model pengajaran sinektik

di Sanggar 'Kampung Seni \& Wisata Manglayang'

tif namun dapat dilaksanakan oleh semua peserta didik dalam jumlah yang banyak (75 orang), 3) model pembelajaran menuntut kreativitas dan keaktifan instruktur sehingga mampu mestimulus instruktur untuk aktif dan kreatif dalam menghadapi peserta didik mengingat kondisi psikologis peserta didik yang masih cenderung belum mandiri, 4) model pembelajaran menumbuhkan inspirasi pengelola sanggar/instruktur untuk mengembangkan penerapan materi dan penggunaan media pembelajaran lain yang berbasis lingkungan sesuai dengan tahap perkembangan peserta didik yang dapat diaplikasikan dalam layanan kunjungan peserta didik lainnya di sanggar tersebut. Aspek lain yang membedakan adalah pada tahap akhir yakni peserta didik tidak dituntut untuk melakukan pendeskripsian hasil kreativitas atau membuat perbandingan melainkan digantikan dengan kegiatan unjuk kerja yang menampilkan hasil kreativitasnya secara berkelompok dengan bimbingan instruktur.

Berdasarkan prosesnya diperoleh temuan hasil pembelajaran sebagai berikut: 
1. Tahap persiapan: dilakukan bersama antara pengelola sanggar dan institusi siswa didik untuk: a) identifikasi kebutuhan belajar pihak warga belajar, b) identifikasi potensi yang menunjang untuk pembelajaran, c) analisis kebutuhan dan potensi materi yang tersedia.

2. Perencanaan pembelajaran: perencanaan dilaksanakan secara bersama antara pengelola sanggar/instruktur menyangkut: a) perumusan tujuan, b) penetapan bahan/materi belajar, c) penetapan instruktur, d) penetapan strategi pembelajaran, e) penetapan waktu pembelajaran, f) penetapan sarana dan media pembelajaran. Pihak pengelola sanggar juga menghimpun potensi yang mendukung, dan mengatur pemanfaatannya.

3. Tahap pelaksanaan: pelaksanaan pembelajaran menggunakan model pengajaran sinektik berbasis seni. Secara non formal strategi pembelajaran menggunakan pembelajaran partisipatif dengan fokus pembelajaran memanfaatkan potensi seni budaya lokal sebagai materi yang dikembangkan dalam pembelajaran.

4. Tahap evaluasi: pelaksanaan evaluasi dilakukan bersama antara pengelola sanggar yang juga berperan sebagai instruktur pembelajaran dan pihak warga belajar (guru). Komponen yang dievaluasi menyangkut pelaksanaan pembelajaran dan hasil belajar yang dicapai siswa didik sebagai warga belajar menyangkut ranah kognitif, afektif, dan psikomotor.

5. Tindak lanjut/pengembangan pada kesempatan selanjutnya instruktur telah melakukan upaya mengembangkan: tema dan materi pembelajaran dengan menggunakan media lain yang berbasis lingkungan sehingga menumbuhkan karya inovatif antara lain: pembelajaran gerak tari boboko, cetok, tutunggulan, nga- ronda, kentongan yang distimulus dari lingkungan sekitar sebagai wujud diterapkannya pembelajaran seni berbasis seni budaya setempat.

Berdasarkan pengamatan pada praktik pembelajarannya, Ria mengembangkan konsep pembelajaran partisipatif dengan pendekatan yang humanis, yang menekankan pada pentingnya kebutuhan sasaran (objek) dalam belajar, dengan harapan peserta didik akan mampu mempersepsi pengalamannya termasuk pengalaman belajarnya, dan mampu menginternalisasi pengalamannya secara aktif dalam kehidupannya. Peserta didik memiliki pemahaman bahwa anggota tubuh dapat dimaksimalkan fungsinya secara kreatif dalam kehidupan. Inovasi yang dilakukan Ria dalam hal ini adalah membantu tumbuhnya pengalaman belajar baru yang dirasakan manfaatnya oleh peserta didik yang belum pernah mereka dapatkan sebelumnya yakni bermain musik imitatif dan pembelajaran gerak kreatif. Melalui pengenalan perilaku dan keindahan binatang memberi pengalaman belajar baru yang diinspirasikan dari halhal yang mereka kenal sehari-hari guna menumbuhkan sikap inovatif dan kreatif. Hal itu sesuai dengan konsep pembelajaran humanis bahwa proses pembelajarannya membantu mempercepat serta memudahkan timbulnya gagasan baru.

Pemilihan model pembelajaran sinektik dirasakan sesuai dengan sifat dan materi yang diajarkan, yang dipengaruhi oleh tujuan yang akan dicapai dalam pengajaran sesuai kemampuan peserta didik. Kawi dan Ria dalam hal ini memerhatikan pemilihan tema berdasarkan aspek berikut: tema sederhana dan yang sekiranya bermakna guna proses pembelajaran selanjutnya. Hal ini disesuaikan dengan 
perkembangan psikologis anak, yakni dapat diminati oleh peserta didik dengan responsyang baik. Pemilihan tema cukup otentik, menarik dan merupakan peristiwa yang terjadi di seputar lingkungan peserta didik yang berbasis pada lingkungan budaya setempat serta mempertimbangkan kemudahan dalam penggunaan media pembelajaran yang fleksibel.

Model pembelajaran partisipatif yang dilaksanakan secara proses menciptakan situasi belajar yang menyenangkan (joyfull learning) serta mendorong peserta didik untuk aktif belajar dan berpikir kreatif, sementara itu instruktur melakukan upaya yang inovatif sesuai sasaran pembelajaran. Berdasarkan hasil evaluasi dengan menggunakan hasil komparasi pre-test dan post-test dengan menggunakan uji ' $\mathrm{t}$ ' diperoleh data adanya peningkatan hasil yang signifikan antara pre-test dengan posttest yang mencakup ranah kognitif, afektif dan psikomotor. Hasil yang diperoleh adalah: 1) terjadi perubahan yang signifikan antara pengetahuan awal peserta didik dengan pengetahuan akhir peserta didik setelah mengikuti kegiatan dengan model sinektik. Hasil pengujian dengan uji ' $t$ ' dalam aspek pengetahuan untuk peserta didik tingkat awal (usia 6 tahun) yakni: 10,65 . Terjadi perubahan yang signifikan antara sikap awal peserta didik dengan sikap akhir peserta didik setelah mengikuti pembelajaran dengan menerapkan model sinektik. Hasil pengujian dengan uji ' $t$ ' dalam aspek sikap untuk peserta didik kelompok I yakni: 14,80.

Demikian pula terjadi perubahan yang sangat signifikan antara keterampilan awal peserta didik dengan keterampilan akhir peserta didik setelah mengikuti kegiatan pembelajaran dengan menerapkan model pembelajaran sinektik. Hasil pengujian dengan uji ' $\mathrm{t}$ ' dalam aspek keterampilan/ motorik untuk peserta didik yakni 19,50 sangat tinggi.

Secara produk/hasil mencapai tujuan pembelajaran, yaitu mampu meningkatkan kemampuan aspek kognitif, afektif, dan psikomotor peserta didik sesuai dengan standar atau kompetensi yang ditentukan yakni:

1. Secara afektif

a. Mengenal dan menyayangi ciptaan Tuhan: mampu mengidentifikasi gerakgerik binatang dan mengaguminya, dan menyayangi binatang karena keindahannya.

b. Terbiasa berperilaku baik bersama teman-teman selama proses belajar, berkata sesuai dengan perintah instruktur, kedisiplinannya nampak dari keseriusan belajar, mampu menjawab pertanyaan dengan komunikasi yang baik dengan instruktur.

c. Berperilaku saling hormat menghormati, mendengarkan dan memperhatikan teman (tampak saat kerja kelompok).

d. Bersikap ramah dalam menjawab sapaan namun tetap serius mengerjakan tugas (tugas tampaknya tidak menjadi beban yang berat karena mereka pahami)

e. Menunjukkan sikap kerjasama; dapat melaksanakan tugas kelompok, tidak bermain sendiri, memuji dan menghargai hasil kerja kelompok teman lainnya.

f. Menunjukkan rasa percaya diri: berani mengemukakan pendapat dan berani memberikan keterangan atas hasil pekerjaannya.

g. Mau peduli terhadap lingkungan, hal ini tampak setelah melaksanakan tugas peserta didik membersihkan tempat dengan bimbingan gurunya, membuang sampah bekas mereka makan pada tempat khusus. 
h. Bertanggung jawab melaksanakan kegiatan kelompok sampai selesai bersama-sama.

i. Pengamatan lain yakni terhadap aspek kemampuan bahasa. Musik mulut dapat dijadikan sebagai media berlatih kelancaran berbahasa, yang ciri-cirinya secara khusus sebagai berikut: memiliki perbendaharaan kata misalnya,: kata 'kepak-kepak, kukuruyuk/kongkorongok, dan petok-petok', yang bersumber dari bunyi ayam. Para peserta didik mampu membedakan bunyi suara, bunyi bahasa, dan mengucapkannya dengan lafal yang benar. Mereka pun mampu membedakan dan menirukan kembali bunyi suara tertentu seperti halnya suara ayam tersebut secara berselang-seling sesuai urutan geraknya.

\section{Secara kognitif}

a. Peserta didik mampu memahami konsep sederhana, benda disekitar/binatang menurut bentuk, jenis, dan ukuran. Mengelompokkan warna suara menurut ciri-ciri tertentu seperti warna suara hewan dan mengenal perbedaan antara karakter warna suara tersebut. Peserta didik pun akhirnya mampu membedakan antara warna suara, dan gerak serta warna dari hewan yang digambarnya.

b. Peserta didik memahami hitungan dan pengulangannya terkait dengan gerak tari yang dipraktikannya, yakni menyebut hitungan: ' $t u$ ' untuk satu, ' $w a$ ' (dua), ' $g a$ ' (tiga), 'pat' (empat). Mampu menghubungkan antara lambang bilangan dengan gerak.

3. Secara motorik

Konsep motorik, dalam hal ini terkait dengan konsep gerak tari. Berdasarkan kompetensi dasar, standar kompetensi dan indikatornya yakni:

a. Peserta didik mampu melakukan aktivitas fisik secara terkoordinasi, memi- liki kelenturan, kelincahan, keseimbangan, dan keberanian. Hasil belajar tersebut mengindikasikan bahwa $90 \%$ peserta didik dapat menggerakkan tangan dan badannya secara terkoordinasi.

b. Peserta didik dapat menyajikan musik mulut yang mereka buat terkoordinasi dengan gerak dengan menggunakan kata-kata: kukuruyuk, kepak-kepak dan petok-petok serta dapat menggerakan tangan ke arah samping, ke arah depan, berkeliling, melenggak-lenggok, dan mengangguk. Mereka juga mampu mengayunkan langkah, dan mengayunkan lengan secara koordinatif dengan meniru gerak binatang 'ayam' atas bimbingan instruktur sesuai irama musik yang dibawakan.

Desain akhir Syntax model pengajaran sinektik dapat dilihat pada tabel 3.

\section{Keterbatasan penelitian}

Penerapan syntax pembelajaran sinektik bertujuan guna mengembangkan proses pembelajaran guna meningkatkan kemampuan memecahkan masalah, ekspresi kreatif, empati, dalam hubungan sosial. Namun dalam pengembangan analoginya mendapat keterbatasan mengingat kondisi peserta didik pada tahap tersebut masih memerlukan bimbingan sehingga masih terdapat sifat intervensi instruktur yang mewarnai proses belajar tersebut. Oleh karena itu agar mendapat hasil maksimal perlu dicoba penerapan model sinektik pembelajaran seni di sanggar itu dengan menerapkannya pada usia yang berbeda sehingga temuannya lebih kredibel.

Sesuai dengan metodologi yang diterapkan yakni metode eksperimen, akan tetapi karena keterbatasan biaya, waktu, 


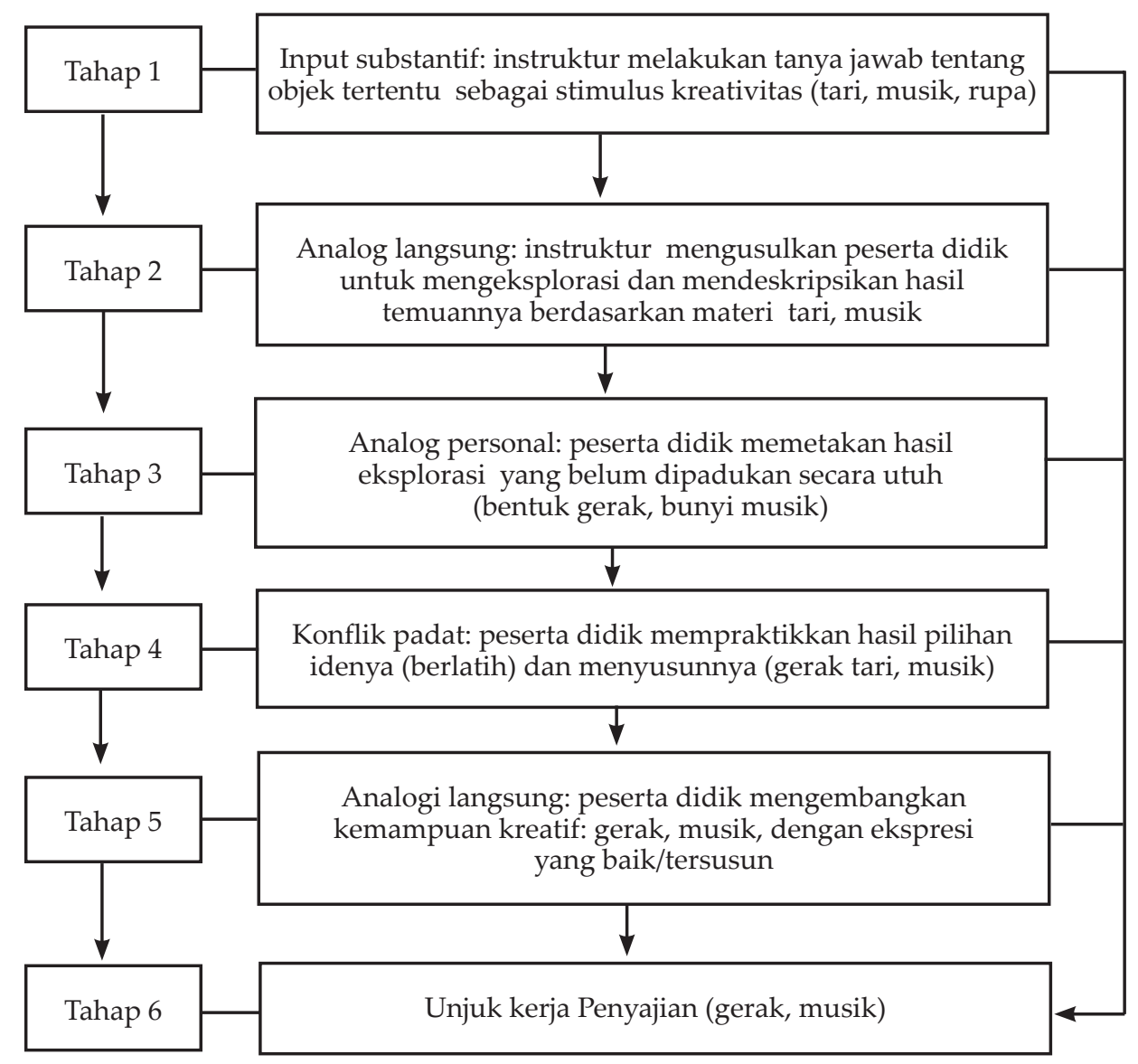

Tabel 3

Syntax model pengajaran sinektik akhir yang diaplikasikan di Kampung Seni \& Wisata Manglayang (2010)

dan kesempatan, maka penelitian ini mengandung sifat invalidity yang bersumber dari perbedaan khas. Faktor pembeda lainnya yakni sifat eksperimen semu (the one shotcase study) sehingga metodologi yang dikembangkan memiliki keterbatasan khusus yang berbeda dengan jenis eksperimen lainnya. Aspek lain yang mendapat keterbatasan yakni pemanfaatan media berbasis lingkungan dalam pembelajaran yang masih belum maksimal akibat kesempatan yang terbatas dalam melaksanakan penelitian. Pemanfaatan media yang variatif berbasis lingkungan tersebut apabila terus dikembangkan kelak akan menjadi salah satu ciri khas yang membedakan pembela- jaran di sanggar Kampung Seni dibanding sanggar lainnya.

\section{Penutup}

Secara umum penelitian ini telah mencapai tujuan, yakni menghasilkan model pembelajaran dengan menerapkan pembelajaran model sinektik, pada peserta didik usia tingkat awal di sanggar Kampung Seni \& Wisata Manglayang. Berdasarkan pada hasil penelitian dapat disimpulkan beberapa hal berikut.

Proses pembelajaran dapat dilakukan sesuai dengan rencana mengingat keter- 
laksanaan pembelajaran ditunjang dengan kelengkapan sarana dan prasarana yang disiapkan oleh Sanggar Kampung Seni \& Wisata Manglayang. Kondisi tersebut mewujudkan kriteria bentuk sanggar seni yang kapabilitasnya memenuhi syarat sebagai wahana pariwisata pendidikan seni bagi masyarakat.

Proses pembelajaran dan pelatihan seni bagi para warga yang belajar di Sanggar Kampung Seni pada intinya adalah lebih berorientasi pada warga belajar dan kebutuhan belajarnya, hasil belajarnya langsung dapat dimanfaatkan oleh warga belajar. Konsepsi belajar di sanggar Kampung Seni bukan hanya upaya perubahan sebatas pengetahuan dan ketrampilan seni saja namun juga mencakup perubahan pada aspek-aspek kognitif, afektif, dan psikomotorik. Program-program pelatihan seni di Kampung Seni sesuai karakteristiknya mempunyai program yang tidak selalu ketat dan tidak selalu berjenjang walaupun dapat berurutan, dan dalam penyelenggaraan programnya antara kebutuhan belajar dan kondisi setempat lebih diperhatikan, sehingga kegiatan pembelajarannya dapat bervariasi dan luwes.

Berdasarkan efektivitasnya implementasi pembelajaran tersebut mampu meningkatkan kualitas dalam berbagai hal antara lain:

1) Proses pembelajaran dirasakan sangat bermakna karena dalam setiap proses pembelajaran sebelumnya dilakukan perencanaan dengan melibatkan pihak pengelola dengan warga belajar (pembimbing peserta didik). Pihak pengelola sanggar melayani kebutuhan belajar yang paling tepat diberikan dan mengetahui sistem pelaksanaan pembelajaran yang tepat bagi peserta didik. Melalui pembelajaran yang humanis maka terjalin komunikasi yang harmonis yang dapat menimbul- kan suasana pembelajaran yang kondusif.

2) Pengembangan materi dengan tahap-tahap pembelajaran yang efektif, berdampak positif terhadap pemberdayaan potensi seni budaya lokal dalam proses pembelajaran. Dampak yang positif yang timbul adalah melalui penggunaan media yang memanfaatkan alat-alat keseharian, peserta didik dapat mengenal berbagai media/sarana yang dimanfaatkan dalam lingkungan kehidupan masyarakat pada umumnya.

3) Materi pembelajaran seni menjadi lebih variatif karena peserta didik selain memperoleh apresiasi seni budaya tradisi masyarakat setempat, juga dapat menerima pembelajaran seni budaya yang inovatif karena dalam proses pembelajarannya menjadi lebih aktif dan kreatif.

4) Berdasarkan hasil evaluasi terhadap pembelajaran dengan menggunakan analisis komparasi hasil pre-test dan post-test dan dengan menggunakan uji ' $\mathrm{t}$ ' diperoleh data adanya peningkatan hasil yang signifikan antara ranah kognitif, afektif, dan psikomotor. Penerapan model sinektik berbasis seni untuk usia tingkat awal dapat meningkatkan eksistensi sanggar sebagai wahana pendidikan seni di Sanggar Kampung Seni \& Wisata Manglayang.

Saran-saran yang dapat penulis kemukakan adalah, perlunya standarisasi bentuk sanggar seni yang mengembangkan fungsinya sebagai wahana pariwisata pendidikan seni yang berbasis pada seni budaya tradisi masyarakat.

Perlunya penggalian dan pemberdayaan potensi materi seni dan media pembelajaran yang berbasis pada lingkungan setempat dalam pengembangan pembelajaran di sanggar seni yang berbasis pariwisata pendidikan agar pembelajaran seni lebih variatif dan lebih bermakna. 


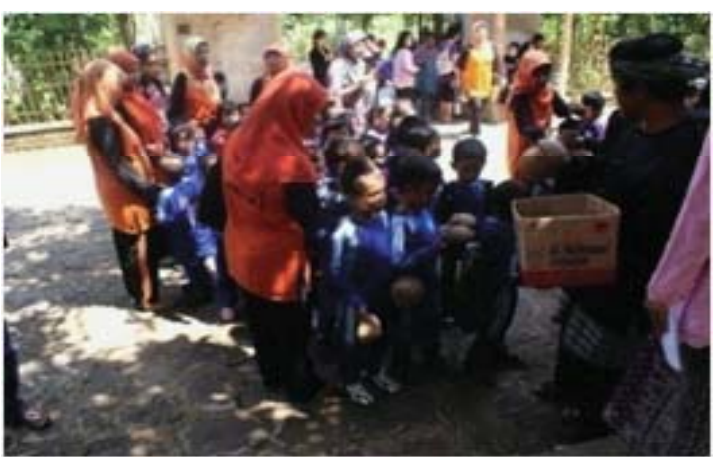

Foto 1

Peserta didik memasuki wahana Sanggar Kampung Seni (Dok. Karwati, 2010)

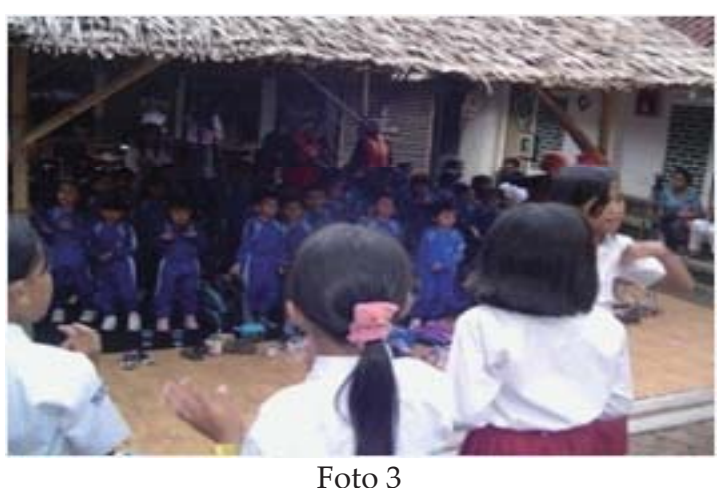

Peserta didik mengimitasi gerak ayam dengan bunyi "kukuruyuk"

(Dok. Karwati, 2010)

\section{DAFTAR PUSTAKA}

Creswell, John W.

2003 Research Design. Second Edition. Thousand Oak London. New Delhi: Sage Publication Inc. to Theori and Methods; Allyn and Bacon.

Hamzah B. Uno

2007 Pembelajaran Menciptakan proses be lajar Mengajar yang. Kreatif dan Efek tif. Jakarta: Bumi Aksara.

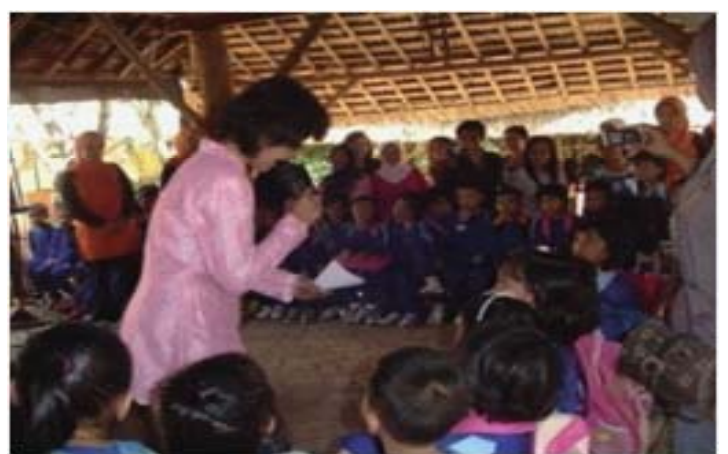

Foto 2

Instruktur Ria dalam suasana awal pembelajaran (stimulus pembelajaran) (Dok. Karwati, 2010)

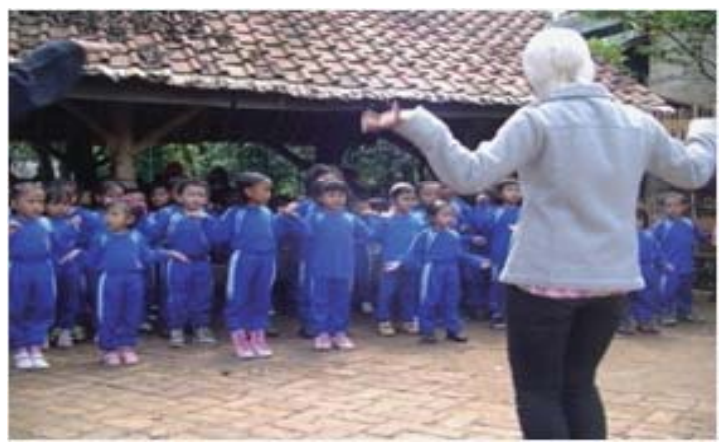

Foto 4

Imitasi gerak kepak-kepak sayap 'ayam' dalam kunjungan pariwisata pendidikan seni di Kampung Seni \& Wisata Manglayang (Dok. Karwati, 2010)

Joyce, Bruce, Marsha Weil, Emily Calhoun 2009 Models Of Teaching. Yogyakarta: Pustaka Pelajar.

\section{Dahlan}

1984 Model-model Mengajar. Bandung: CV. Diponegoro.

Sudjana, Djudju

2005 Metode dan Teknik Pembelajaran Partisipatif. Bandung: Falah Production. 
Sugiyono

2007 Memahami Penelitian Kualitatif. Bandung: CV Alfabeta.

\section{Metode penelitian Kuantitatif, Kuali- \\ tatif dan $R$ \& D. Bandung: Alfabeta. \\ $\mathrm{Cv}$.}

Tilaar

1999 Pendidikan, Kebudayaan dan Masyasrakat Madani Indonesia. Bandung: PT. Remaja Rosdakarya. 